\title{
Evaluation of Polyphenol Content and Antioxidant Capacity of Fruits and Vegetables Using a Modified Enzymatic Extraction
}

\author{
Rudy Álvarez ${ }^{1}$, Héctor Araya ${ }^{1}$, Rosa Navarro-Lisboa ${ }^{2 *}$ and Carol Lopez de Dicastillo ${ }^{3}$ \\ ${ }^{1}$ University of Chile and the School of Nutrition, Faculty of Medicine, Department of Nutrition, \\ El Líbano 5524 Macul, 7830490 Santiago, Chile \\ ${ }^{2}$ University of Santiago of Chile, Faculty of Technology, Department of Science and Food Technology, \\ Obispo Umaña 050, Estación Central, 9170200 Santiago, Chile \\ ${ }^{3}$ University of Santiago of Chile, Faculty of Technology, Department of Science and Food Technology, \\ Center for the Development of Nanoscience and Nanotechnology (CEDENNA), \\ Food Packaging Laboratory (LABEN-CHILE), Estación Central, 9170200 Santiago, Chile
}

Received: October 27, 2015 Accepted: May 12, 2016

\begin{abstract}
Summary
Fruits and vegetables are considered a good source of polyphenols and antioxidant capacities which are beneficial in protecting the human body against damage induced by reactive species. The objective of this work is to conduct an assessment of the polyphenol content and antioxidant activities of different fruit (kiwi, pear, green apple, raspberry, blackberry, strawberry and blueberry) and vegetable (pumpkin, green and red pepper) extracts using both chemical extraction and a modified in vitro digestive enzymatic extraction in order to compare results. Polyphenol content and antioxidant capacity of different fruits, vegetables and fruit juices were determined by Folin-Ciocalteu and FRAP methods, respectively. It was observed that polyphenol content expressed as gallic acid equivalents of extracts obtained with the two extraction methods was significantly $(\mathrm{p}<0.05)$ different (on average 310.3 and $231.8 \mathrm{mg}$ per $100 \mathrm{~g}$ of fresh sample in enzymatic and methanolic extracts, respectively). Antioxidant capacity was also significantly $(p<0.05)$ different in the extracts obtained by the two methods, with higher values in enzymatic extracts $(1.91 \mathrm{mmol}$ of $\mathrm{Fe}^{2+}$ per $100 \mathrm{~g}$ of fresh sample). Analyses of apple samples with and without skin also revealed important differences related to methodology and composition. Additionally, the original enzymatic extraction method was improved to avoid interferences caused by the presence of protein residues in the extract.
\end{abstract}

Key words: antioxidant capacity, enzymatic extraction, fruits and vegetables, methanolic extraction, polyphenols

\section{Introduction}

Fruits and vegetables are an essential part of the human diet, and several epidemiological studies show that the content of natural antioxidants, especially flavonoids, may be beneficial in protecting the human body against damage induced by reactive species. This is important for maintaining physiological redox equilibrium $(1,2)$. These foods supply several antioxidants, such as ascorbic acid (vitamin C), tocopherols and tocotrienols (vitamin E), carotenoids (provitamin A), and several phenolic compounds (flavones, isoflavones, flavanones, anthocyanins and catechins) $(3,4)$.

Polyphenols are compounds with aromatic structure, with one or more hydroxyl groups, which undergo physical and chemical changes by action of enzymes and 
chemical reactions in plants caused by the activity of other active components, such as coumaroyl and malonyl coenzyme A. These changes contribute to the process of maturation and physical alterations of the vegetable matrix (5).

Nowadays, the extraction and purification of antioxidants from natural sources is required, since these bioactive substances are often used in functional foods, food additives and nutraceutical industries (3). Even more, the principal objective in extracting phenolics from their plant sources is to liberate these compounds, either through rupturing plant tissue or a process of diffusion (6). Overall, using these conventional methods may result in the degradation of some chemically sensitive phenols due to intensive mechanical disruption. The involvement of long extraction periods, severe heating conditions and extensive use of organic solvents favour the release of oxidative enzymes that promote degradation (7). Different chemical methods for extraction of polyphenols from food matrices have been applied in order to study the polyphenol content of food. Most of these methods use organic solvents with acidic $\mathrm{pH}$ and high temperatures during standardized times to optimize the extraction of compounds. However, these methods may have lower extraction efficiency (8-11) and it is necessary to purify the obtained extract or remove interfering components in order to improve the antioxidant activity of the extract.

On the other hand, it has been shown that the amount of antioxidants extracted from food matrices through in vitro digestive enzymatic treatments that mimic conditions in the gastrointestinal tract was higher than the values obtained from usual extraction of organic compounds from aqueous solutions (12). The determination of polyphenol content and antioxidant capacity of food extracts are also important to know the health potential of different foods. Therefore, various methods have been developed to estimate the antioxidant capacity (13-15) and the results can elucidate the recommendations for food consumption.

Therefore, the aim of this work is to conduct an assessment of the polyphenol content and antioxidant activities of different fruit and vegetable extracts using both chemical and in vitro digestive enzymatic extractions.

\section{Materials and Methods}

\section{Reagents and samples}

Folin-Ciocalteu reagent, sodium carbonate and pepsin were purchased from Merck (Darmstadt, Germany). The 2,4,6-tri(2-pyridyl)-s-triazine (TPTZ), ferric chloride, methanol, acetate and gallic acid were obtained from Fluka Chemicals Ltd. (Gillingham, UK). Pancreatin, lipase, bile salts, $\alpha$-amylase and amyloglucosidase were purchased from Sigma-Aldrich (St. Louis, MO, USA).

Fruits and vegetables (kiwi, pear, pumpkin, green apple, blackberry, raspberry, strawberry, blueberry, green and red peppers) were purchased from a local supermarket in Santiago province (Santiago, Chile). All fruits and vegetables were fresh and free from visible blemishes or defects, except for strawberry, which was purchased frozen. Natural kiwi, orange and green apple juices were obtained by squeezing and filtering fresh fruits and then used for analysis. Green apple with and without skin was studied. The skin to flesh ratio was 1:8 (by mass).

\section{Methanolic extraction}

Approximately $1 \mathrm{~g}$ of each fresh fruit or vegetable was ground in a mortar to fine particles and put in $10 \mathrm{~mL}$ of methanol. After $1 \mathrm{~h}$ of extraction with continuous magnetic stirring at $200 \mathrm{rpm}$ and room temperature $\left(20^{\circ} \mathrm{C}\right)$, the extract was centrifuged at $1000 \times g$ for $20 \mathrm{~min}$. The supernatant was recovered and stored at $-18{ }^{\circ} \mathrm{C}$ until analysis. Extractions were performed in triplicate and light exposure was avoided during the process (9). Extractions of juice samples $(1 \mathrm{~mL})$ followed the same methodology.

\section{Enzymatic extraction}

The enzymatic method was based on the methodology proposed by Saura-Calixto et al. (9), which separated the process into two main parts: (i) enzymatically digestible fraction, and (ii) colonic fermentation in vitro.

This study was focused on the improvement of the first stage of the process, where the action of digestive enzymes was simulated on a food matrix at gastric and small intestine levels. Briefly, $900 \mathrm{mg}$ of fruit or vegetable sample or $0.9 \mathrm{~mL}$ of fruit juice sample were incubated with $0.2 \mathrm{~mL}$ of pepsin $(300 \mathrm{mg} / \mathrm{mL}$ solution in $0.2 \mathrm{M} \mathrm{HCl} / \mathrm{KCl}$ buffer, $\left.\mathrm{pH}=1.5,40{ }^{\circ} \mathrm{C}, 1 \mathrm{~h}\right), 1 \mathrm{~mL}$ of pancreatin $(5 \mathrm{mg} / \mathrm{mL}$ solution in $0.1 \mathrm{M}$ phosphate buffer, $\mathrm{pH}=7.5,37^{\circ} \mathrm{C}, 6 \mathrm{~h}$ ), and $1 \mathrm{~mL}$ of $\alpha$-amylase $(120 \mathrm{mg} / \mathrm{mL}$ solution in $0.1 \mathrm{M}$ Tris-maleate buffer, $\mathrm{pH}=6.9,37^{\circ} \mathrm{C}, 16 \mathrm{~h}$ ). Then, samples were centrifuged (for $15 \mathrm{~min}$ at $3000 \times g$ ) and supernatants were removed. Residues were washed twice with $5 \mathrm{~mL}$ of distilled water, and all supernatants were combined. Each supernatant was incubated with $100 \mu \mathrm{L}$ of amyloglucosidase for $45 \mathrm{~min}$ at $60{ }^{\circ} \mathrm{C}$ (13). Both methanolic extracts and those obtained by extraction with digestive enzymes were used to determine the antioxidant capacity and polyphenol content in fruit and vegetable extracts and fruit juices.

\section{Protein precipitation assay}

Enzymatic extraction involves the use of several reagents, principally enzymes that could interfere with each other during the analysis of polyphenols and antioxidant activities. Therefore, in order to evaluate possible interferences during spectrophotometric analysis in Folin-Ciocalteu and FRAP tests, a control sample consisting of a mixture of all enzymes was treated with trichloroacetic acid (TCA) reagent to precipitate proteins. Thus, a volume of $1 \mathrm{~mL}$ of a control sample supernatant (or $0.05 \mathrm{mg}$ of albumin used for calibration) was diluted in $12.5 \mathrm{~mL}$ of phosphate-buffered saline (PBS) and $2.5 \mathrm{~mL}$ of TCA solution (60\%). The mixture was centrifuged at $10000 \times g$ at $4{ }^{\circ} \mathrm{C}$ for $20 \mathrm{~min}$. Protein quantification, polyphenol content and antioxidant capacity of the supernatant (control samples) were analyzed before and after protein precipitation.

\section{Protein quantification}

Protein concentration was determined by Bradford assay (16). A volume of $200 \mu \mathrm{L}$ of Bradford reagent diluted with deionized water $(20 \%)$ was added to $10 \mu \mathrm{L}$ of the supernatant. The mixture was thoroughly agitated for $1 \mathrm{~min}$ 
using a vortex mixer, then incubated for $5 \mathrm{~min}$ at room temperature and the absorbance was measured at $\lambda=595 \mathrm{~nm}$. All analyses were performed in triplicate. Results were expressed as albumin equivalents in $\mathrm{mg}$ of albumin per $\mathrm{mL}$ of supernatant, using a calibration curve.

\section{Determination of phenolic content}

Total phenolic content of each extract was determined using the Folin-Ciocalteu reagent according to the method of Singleton and Orthofer (17). A volume of $0.5 \mathrm{~mL}$ of Folin-Ciocalteu reagent previously diluted with distilled water $(1: 10)$ was mixed with $0.1 \mathrm{~mL}$ of each extract (methanolic or enzymatic). The solution was allowed to stand for $5 \mathrm{~min}$ at $25^{\circ} \mathrm{C}$ before adding $1.7 \mathrm{~mL}$ of sodium carbonate solution $(20 \%)$. Then, $10 \mathrm{~mL}$ of distilled water were added to the mixture, and the absorbance was measured at $\lambda=735 \mathrm{~nm}$ after $20 \mathrm{~min}$ of incubation with agitation at room temperature. Results were expressed in $\mathrm{mg}$ of gallic acid equivalents (GAE) per $100 \mathrm{~g}$ of fresh sample.

\section{Determination of antioxidant capacity}

Antioxidant capacities of the samples were determined using FRAP assay (12). An aliquot of the samples $(0.05 \mathrm{~mL})$ was mixed with $1.5 \mathrm{~mL}$ of ferric TPTZ reagent (sodium acetate buffer $300 \mathrm{mM}, \mathrm{pH}=3.6,10 \mathrm{mM}$ ferric 2,4,6-tripyridyl-s-triazine) in a $20 \mathrm{mM} \mathrm{FeCl} \cdot 6 \mathrm{H}_{2} \mathrm{O}$ solution. Tubes were incubated for $4 \mathrm{~min}$ at $37{ }^{\circ} \mathrm{C}$ and the change in the absorbance was measured at $\lambda=593 \mathrm{~nm}$. The results of the antioxidant capacity of fruit extracts were expressed in mmol of $\mathrm{Fe}^{2+}$ per $100 \mathrm{~g}$ of sample.

Generally, it is recommended to use more than one method for evaluating the antioxidant capacity of complex heterogeneous systems like foods, as the antioxidants may respond in a different manner to different radical or oxidant sources. Nevertheless, in this work antioxidant activity and polyphenol content, measured though FRAP and Folin-Ciocalteu methods, respectively, are the only two tools to obtain data for a comparative study between both extraction methods.

\section{Statistical analysis}

Each analysis was done at least in triplicate and the results were expressed as a mean value with standard deviation (S.D.). Groups representing enzymatic and methanol extracts were compared using Tukey's test. Relationships between variables were assessed by linear regression. The normal distribution of the variables was verified by Shapiro-Wilk test. Statgraphics Plus software package v. 2.1 (Statistical Graphics Corp., Rockville, MD, USA) was used in all statistical analyses.

\section{Results and Discussion}

\section{Protein precipitation results}

Enzymatic extraction was modified to avoid overestimation of results as a consequence of the use of the mixture of enzymes in this method (17). Therefore, it was necessary to precipitate the protein before each analysis. The concentration of polyphenols and antioxidant activity of control samples (mixture of enzymes used in the enzymatic extraction) were measured before and after protein precipitation. Before protein precipitation, protein concentration in the control sample was determined to be (50 \pm 20$) \mathrm{mg}$ of albumin per L using Bradford assay. Polyphenol content of control sample before protein precipitation expressed as GAE was (100 \pm 1$) \mathrm{mg}$ per $100 \mathrm{~g}$ and after the precipitation it was reduced to $(7 \pm 1) \mathrm{mg}$ of GAE per $100 \mathrm{~g}$. On the other hand, control sample had an antioxidant activity of $(1.33 \pm 0.02) \mathrm{mmol}$ of $\mathrm{Fe}^{2+}$ per $100 \mathrm{~g}$, which was reduced to $(0.23 \pm 0.05) \mathrm{mmol}$ of $\mathrm{Fe}^{2+}$ per $100 \mathrm{~g}$ after the precipitation.

\section{Polyphenol content of enzymatic and methanolic extracts}

Polyphenol content of fresh fruit and vegetable extracts obtained using both extraction methods is shown in Table 1. Polyphenol content of fruit and vegetable extracts obtained with enzymatic extraction was significantly higher than that obtained with methanolic extraction $(p<0.05)$. Concentration of polyphenols in blackberry, raspberry, strawberry and blueberry fruits were very similar, although statistically different, and their reduction was smaller (5-13\%) than after enzymatic extraction, while the reduction in other fruits and vegetables was 40-70\%. These results are in accordance with research studies that showed that proanthocyanidins, anthocyanins and condensed tannins present in berries were released less efficiently than other polyphenols at the gastric level and small intestine (18). Another in vivo study indicated that polyphenols in berries may inhibit the enzymes involved in the hydrolysis of carbohydrates, such as $\alpha$-amylase and glucose, reducing their release and absorption in the small intestine (19). Nevertheless, the samples such as kiwi, green pepper, pear, green apple and pumpkin have shown the highest difference between both extractions; these samples extracted enzymatically had between 36

Table 1. Polyphenol content and antioxidant capacity of extracts of fresh fruits and vegetables obtained by enzymatic and methanolic extractions

\begin{tabular}{|c|c|c|c|c|}
\hline \multirow[b]{3}{*}{ Sample } & \multirow{2}{*}{\multicolumn{2}{|c|}{ 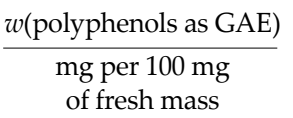 }} & \multirow{2}{*}{\multicolumn{2}{|c|}{$\begin{array}{c}\text { Antioxidant capacity } \\
\begin{array}{c}\mathrm{mmol} \mathrm{Fe}^{2+} \text { per } 100 \mathrm{mg} \\
\text { of fresh mass }\end{array}\end{array}$}} \\
\hline & & & & \\
\hline & $\begin{array}{l}\text { Enzymatic } \\
\text { extraction }\end{array}$ & $\begin{array}{c}\text { Methanolic } \\
\text { extraction }\end{array}$ & $\begin{array}{l}\text { Enzymatic } \\
\text { extraction }\end{array}$ & $\begin{array}{l}\text { Methanolic } \\
\text { extraction }\end{array}$ \\
\hline Kiwi & $(280 \pm 17)^{\mathrm{a}}$ & $(126 \pm 11)^{b}$ & $(0.9 \pm 0.1)^{a}$ & $(1.3 \pm 0.2)^{\mathrm{a}}$ \\
\hline Pear* & $(155 \pm 35)^{a}$ & $(99 \pm 7)^{\mathrm{b}}$ & $(0.54 \pm 0.08)^{b}$ & $(0.68 \pm 0.04)^{\mathrm{a}}$ \\
\hline Green pepper & $(305 \pm 4)^{\mathrm{a}}$ & $(96 \pm 12)^{b}$ & $(0.49 \pm 0.07)^{\mathrm{a}}$ & $(0.46 \pm 0.01)^{\mathrm{a}}$ \\
\hline Red pepper & $(153 \pm 18)^{\mathrm{a}}$ & $(136 \pm 14)^{a}$ & $(0.50 \pm 0.05)^{\mathrm{b}}$ & $(0.61 \pm 0.03)^{\mathrm{a}}$ \\
\hline Pumpkin* & $(141 \pm 31)^{\mathrm{a}}$ & $(60 \pm 12)^{b}$ & $(0.3 \pm 0.1)^{\mathrm{a}}$ & $(0.18 \pm 0.01)^{\mathrm{b}}$ \\
\hline Green apple* & $(286 \pm 1)^{a}$ & $(126 \pm 1)^{b}$ & $(0.80 \pm 0.02)^{\mathrm{a}}$ & $(0.47 \pm 0.02)^{\mathrm{b}}$ \\
\hline Blackberry & $(507 \pm 10)^{\mathrm{a}}$ & $(482 \pm 13)^{\mathrm{b}}$ & $(4.50 \pm 0.07)^{a}$ & $(3.53 \pm 0.01)^{b}$ \\
\hline Raspberry & $(482 \pm 11)^{a}$ & $(444 \pm 10)^{b}$ & $(4.0 \pm 0.1)^{\mathrm{a}}$ & $(3.06 \pm 0.09)^{b}$ \\
\hline Strawberry & $(422 \pm 15)^{\mathrm{a}}$ & $(402 \pm 14)^{\mathrm{b}}$ & $(2.8 \pm 0.2)^{\mathrm{a}}$ & $(2.07 \pm 0.06)^{\mathrm{b}}$ \\
\hline Blueberry & $(548 \pm 1)^{\mathrm{a}}$ & $(475 \pm 34)^{\mathrm{b}}$ & $(5.7 \pm 0.2)^{\mathrm{a}}$ & $(3.7 \pm 0.2)^{b}$ \\
\hline
\end{tabular}

Different letters in superscript indicate significant differences in polyphenol content or antioxidant capacity between the extracts ${ }^{*}$ without peel 
and $68 \%$ higher polyphenol content than those obtained by methanolic extraction. High concentrations of polyphenols obtained by this method could be explained by the efficient hydrolysis of food matrix by enzymes, contributing to the release of polyphenols (20). These results are in accordance with the values reported by Pérez-Jimenez and Saura-Calixto (12), which showed that the content of polyphenols and antioxidant capacity of cereals obtained with enzymatic extraction were significantly higher than those obtained with a methanol extraction.

Some studies indicated that the release of dietary polyphenols is mainly determined by their chemical structure; such as its basic structure, molecular mass, degree of glycosylation and acetylation, conjugation with other phenols, degree of polymerization and solubility (21). Moreover, it has been stated that the most important determinant would be the chemical structure of the glycoside and aglycone attached to the different food components (22).

\section{Antioxidant capacity of enzymatic and methanolic extracts}

There was a good relationship between enzymatic and methanolic extractions in all fruits and vegetables. Some researchers have also found that high polyphenol content leads to high antioxidant capacity. In this case, the values of correlation between the concentration of polyphenols and antioxidant capacity were 87 and $93 \%$ in enzymatic and methanolic extracts, respectively. A weaker correlation between polyphenol content and antioxidant activity is probably because the antioxidant activity is a result of a different type of bioactive component with antioxidant activity, not only polyphenols, such as ascorbic, citric and ferulic acids, commonly present in fruit and vegetables.

The antioxidant activity of enzymatic extracts was significantly higher $(\mathrm{p}<0.05)$ than that of methanolic extracts (Table 1), except in the samples of kiwi, pear and red pepper fruits, which had the lowest values. This suggests that high values of antioxidant capacity could be due to enzymatic action, which contributed to the release of polyphenols, and consequently increased the antioxidant capacity (20). Groups participating in the research of Spanish diet found that over $90 \%$ of the antioxidant capacity was induced by the release of polyphenols from the food matrix, showing that the applied enzymatic method was very efficient (15). Nevertheless, the lower antioxidant activities of kiwi, pear and red pepper fruits might be due to the interaction with other food components that could have influenced the measured antioxidant capacity of these samples (23). Moreover, every sample has a specific chemical composition based on various antioxidant components that determine its antioxidant mechanisms, activity and stability (24).

Table 2 shows the total phenolic and glucose contents, and antioxidant activity of apple extracts obtained using different extraction enzymes. It is evident that enzyme-assisted extraction increased considerably the phenolic and glucose contents, especially when $\alpha$-amylase and amyloglucan were added, which improves the extraction efficiency. The high total phenolic content can be the result of degradation or enzyme-assisted extraction of the cell wall polysaccharides at low temperature.
Table 2. Polyphenol and glucose contents, and antioxidant capacity of apple extracts obtained by different enzymatic treatments

\begin{tabular}{|c|c|c|c|}
\hline \multirow{2}{*}{$\begin{array}{l}\text { Enzymatic } \\
\text { treatment }\end{array}$} & $\begin{array}{l}w \text { (polyphenols } \\
\text { as GAE) }\end{array}$ & $\begin{array}{l}\text { Antioxidant } \\
\text { capacity }\end{array}$ & $w$ (glucose) \\
\hline & $\overline{\mathrm{mg} \text { per } 100 \mathrm{~g}}$ & $\begin{array}{l}\mathrm{mmol} \mathrm{Fe}^{2+} \\
\text { per } 100 \mathrm{~g}\end{array}$ & $\mathrm{~g} / 100 \mathrm{~g}$ \\
\hline Pep & $(38 \pm 1)^{a}$ & $(0.43 \pm 0.01)^{\mathrm{a}}$ & $(71.90 \pm 3.33)^{\mathrm{a}}$ \\
\hline Pep+Pan & $(39 \pm 2)^{a}$ & $(0.53 \pm 0.11)^{\mathrm{b}}$ & $(75.42 \pm 2.21)^{\mathrm{a}}$ \\
\hline Pep+Panc+Lip & $(40 \pm 4)^{\mathrm{a}}$ & $(0.37 \pm 0.12)^{c}$ & $(75.21 \pm 4.33)^{\mathrm{a}}$ \\
\hline Pep+Panc+Lip+Bil & $(40 \pm 3)^{a}$ & $(0.55 \pm 0.23)^{\mathrm{b}}$ & $(77.68 \pm 2.11)^{\mathrm{a}}$ \\
\hline $\begin{array}{l}\text { Pep+Panc+Lip+Bil+ } \\
\alpha \text {-Amyl }\end{array}$ & $(497 \pm 4)^{b}$ & $(1.08 \pm 0.08)^{\mathrm{d}}$ & $(97.3 \pm 2.97)^{\mathrm{b}}$ \\
\hline $\begin{array}{l}\text { Pep+Panc+Lip+Bil+ } \\
\alpha \text {-Amyl+Amylogluc }\end{array}$ & $(514 \pm 3)^{c}$ & $(1.55 \pm 0.06)^{\mathrm{e}}$ & $(98.5 \pm 1.66)^{b}$ \\
\hline
\end{tabular}

Different letters in superscript indicate significant differences in polyphenol content or antioxidant capacity between the added enzymes

Pep=pepsin, Pan=pancreatin, Lip=lipase, Bil=bile, $\alpha-$ Amyl $=\alpha-$ amylase; Amylogluc=amyloglucan

\section{Analysis of fruit juices extracted by different methods}

The polyphenol content and antioxidant capacity were higher in the juice samples extracted by enzymatic method (Table 3), and statistically significant differences were found between the extraction methods $(p<0.05)$.

According to data in Table 1, the antioxidant activity of kiwi fruit was higher in methanolic than in enzymatic extracts, while the contrary was found in kiwi fruit juice (Table 3). This difference between fruit and juice could be explained by the easier accessibility of enzymes in the juice medium.

Table 3. Polyphenol content and antioxidant capacity of fresh fruit juice extracts obtained by enzymatic and methanolic extractions

\begin{tabular}{|c|c|c|c|}
\hline \multirow{3}{*}{ Juice } & \multirow{2}{*}{\multicolumn{2}{|c|}{$\frac{\gamma(\text { polyphenols as GAE })}{\mathrm{mg} \text { per } 100 \mathrm{~mL}}$}} & \multirow{2}{*}{$\frac{\text { Antioxidant capacity }}{\mathrm{mmol} \mathrm{Fe}^{2+} \text { per } 100 \mathrm{~mL}}$} \\
\hline & & & \\
\hline & $\begin{array}{l}\text { Enzymatic } \\
\text { extraction }\end{array}$ & $\begin{array}{c}\text { Methanolic } \\
\text { extraction }\end{array}$ & $\begin{array}{l}\text { Enzymatic Methanolic } \\
\text { extraction extraction }\end{array}$ \\
\hline Kiwi & $(235 \pm 25)^{a}$ & $(135 \pm 6)^{b}$ & $(1.1 \pm 0.1)^{\mathrm{a}} \quad(0.73 \pm 0.02)^{\mathrm{b}}$ \\
\hline Orange & $(155 \pm 6)^{a}$ & $(12 \pm 4)^{\mathrm{b}}$ & $(0.9 \pm 0.1)^{\mathrm{a}}$ \\
\hline Green apple & $(223 \pm 15)^{a}$ & $(112 \pm 3)^{b}$ & $(0.93 \pm 0.03)^{\mathrm{a}}(0.82 \pm 0.05)^{\mathrm{b}}$ \\
\hline
\end{tabular}

Different letters in superscript indicate significant differences in polyphenol content or antioxidant capacity between the extractions

In order to study the differences in polyphenol content and antioxidant capacity between fruit with and without skin, the green apple sample was used to evaluate both extraction methods (Figs. 1 and 2). There was a significant difference in the polyphenol content and antioxidant capacity between the enzymatic and methanolic extracts of samples with and without skin $(p<0.05)$. In the apple samples with skin an increase in polyphenol content of 44 and $66 \%$ was observed in enzymatic and methanolic extracts, respectively. The same trend of antioxi- 


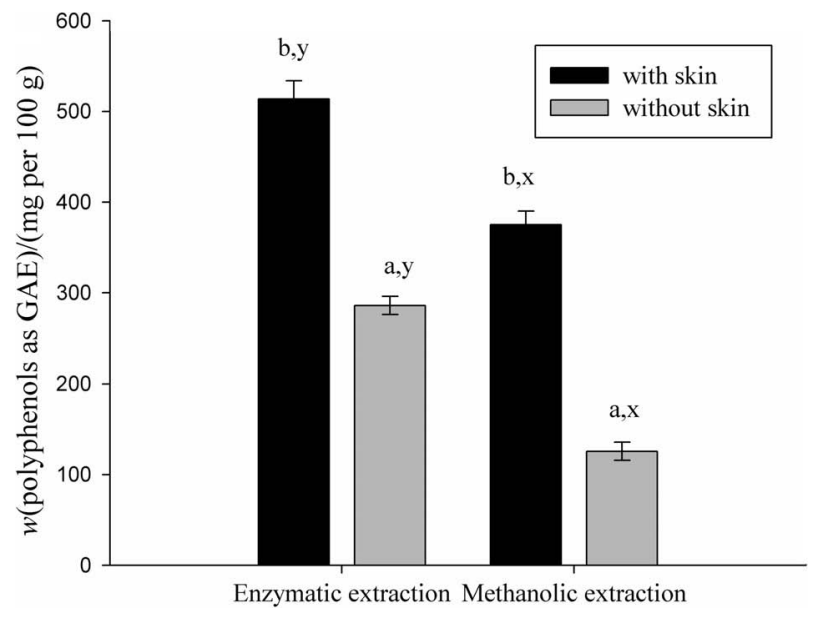

Fig. 1. Polyphenol content of enzymatic and methanolic extracts of apples with and without skin. Letters a and $b$ indicate significant differences between samples with and without skin according to Tukey's test $(\mathrm{p}<0.05)$. Letters $\mathrm{x}$ and $\mathrm{y}$ indicate significant differences between extraction methods according to Tukey's test $(\mathrm{p}<0.05)$. GAE $=$ gallic acid equivalents

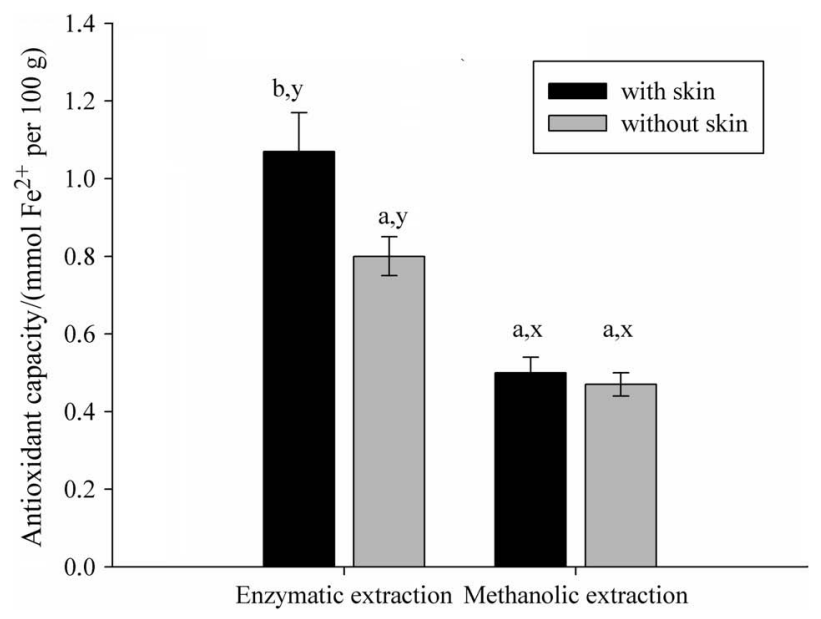

Fig. 2. Antioxidant activities of enzymatic and methanolic extracts of apples with and without skin. Letters a and $b$ indicate significant differences between samples with and without skin according to Tukey's test $(\mathrm{p}<0.05)$. Letters $\mathrm{x}$ and $\mathrm{y}$ indicate significant differences between extraction methods according to Tukey's test $(p<0.05)$

dant activity values was found in enzymatic extract, of approx. $25 \%$ in samples with skin, but only $6 \%$ in methanolic extracts. This could be explained by the location of polyphenols, which are found in greater amounts in the skin. In the apple, about $50 \%$ of the antioxidant capacity is lost when it is peeled, mainly due to the loss of quercetin, a polyphenol present in the skin at a mass fraction of about $1 \mathrm{mg}$ per $\mathrm{g}$ of fruit (25). The results of enzymatic extraction facilitate the understanding of the beneficial effect of enzymes on foods with high polyphenol content and antioxidant capacity.

Figs. 1 and 2 show that polyphenol content and antioxidant capacity of methanolic extracts did not correlate, which was already observed in previous works $(13,26)$.

\section{Conclusions}

In this work, phenolic compounds from enzymatic and methanolic extracts of different fruits, vegetables and fruit juices, and their antioxidant capacity were analysed. The enzymatic extraction clearly showed its effectiveness by enhancing the antioxidant capacity and polyphenol content of extracts. This technique offers an opportunity to develop efficient procedures for the extraction of valuable plant products with applications in the food industries. Also, the original enzymatic method was improved in order to avoid interference by protein residues found in the samples, which was accomplished by protein precipitation.

\section{Acknowledgements}

This research was conducted at the Department of Nutrition, Faculty of Medicine, University of Chile. Author Rosa Navarro-Lisboa acknowledges the financial support of Becas de Doctorado Nacional No. 21130785 from CONICYT.

\section{References}

1. Dani C, Oliboni LS, Vanderlinde R, Bonatto D, Salvador M, Henriques JAP. Phenolic content and antioxidant activities of white and purple juices manufactured with organicallyor conventionally-produced grapes. Food Chem Toxicol. 2007; 45:2574-80. http://dx.doi.org/10.1016/j.fct.2007.06.022

2. Gil MI, Tomás-Barberán FA, Hess-Pierce B, Kader AA. Antioxidant capacities, phenolic compounds, carotenoids, and vitamin $C$ contents of nectarine, peach, and plum cultivars from California. J Agric Food Chem. 2002;50:4976-82. http://dx.doi.org/10.1021/jf020136b

3. Shahidi F, Naczk M. Phenolics in food and nutraceuticals. Boca Raton, FL, USA: CRC Press; 2004. pp. 132-210.

4. Guerrero JC, Ciampi LP, Castilla AC, Medel FS, Schalchli HS, Hormazabal EU, et al. Antioxidant capacity, anthocyanins, and total phenols of wild and cultivated berries in chile. Chil J Agr Res. 2010;70:537-44. http://dx.doi.org/10.4067/s0718-58392010000400002

5. El-Ramady HR, Domokos-Szabolcsy É, Abdalla NA, Taha HS, Fári M. Postharvest management of fruits and vegetables storage. In: Lichtfouse E, editor. Sustainable agriculture reviews, vol. 15. New York, NY, USA: Springer; 2015. pp. 65-152.

http://dx.doi.org/10.1007/978-3-319-09132-7_2

6. Goli AH, Barzegar M, Sahari MA. Antioxidant activity and total phenolic compounds of pistachio (Pistachia vera) hull extracts. Food Chem. 2005;92:521-5. http://dx.doi.org/10.1016/j.foodchem.2004.08.020

7. Zill-e-Huma, Vian MA, Fabiano-Tixier AS, Elmaataoui M, Dangles O, Chemat F. A remarkable influence of microwave extraction: enhancement of antioxidant activity of extracted onion varieties. Food Chem. 2011;127:1472-80. http://dx.doi.org/10.1016/j.foodchem.2011.01.112

8. Saura-Calixto F, Goñi I, Mañas E, Abia R. Klason lignin, condensed tannins and resistant protein as dietary fibre constituents: determination in grape pomaces. Food Chem. 1991;39: 299-309. http://dx.doi.org/10.1016/0308-8146(91)90147-G

9. Saura-Calixto F, Serrano J, Goñi I. Intake and bioaccessibility of total polyphenols in a whole diet. Food Chem. 2007;101: 492-501.

http://dx.doi.org/10.1016/j.foodchem.2006.02.006 
10. D'Archivio M, Filesi C, Vari R, Scazzocchio B, Masella R. Bioavailability of the polyphenols: status and controversies. Int J Mol Sci. 2010;11:1321-42. http://dx.doi.org/10.3390/ijms11041321

11. Arranz S, Silván JM, Saura-Calixto F. Nonextractable polyphenols, usually ignored, are the major part of dietary polyphenols: a study on the Spanish diet. Mol Nutr Food Res. 2010;54:1646-58.

http://dx.doi.org/10.1002/mnfr.200900580

12. Pérez-Jimenez J, Saura-Calixto F. Literature data may underestimate the actual antioxidant capacity of cereals. J Agric Food Chem. 2005;53:5036-40. http://dx.doi.org/10.1021/jf050049u

13. Benzie IFF, Strain JJ. The ferric reducing ability of plasma (FRAP) as a measure of 'antioxidant power': the FRAP assay. Anal Biochem. 1996;239:70-6. http://dx.doi.org/10.1006/abio.1996.0292

14. González-Molina E, Gironés-Vilaplana A, Mena P, Moreno DA, García-Viguera C. New beverages of lemon juice with elderberry and grape concentrates as a source of bioactive compounds. J Food Sci. 2012;77:C727-33. http://dx.doi.org/10.1111/j.1750-3841.2012.02715.x

15. Serrano J, Goñi I, Saura-Calixto F. Food antioxidant capacity determined by chemical methods may underestimate the physiological antioxidant capacity. Food Res Int. 2006;40:1521. http://dx.doi.org/10.1016/j.foodres.2006.07.010

16. Bradford MM. A rapid and sensitive method for the quantitation of microgram quantities of protein utilizing the principle of protein-dye binding. Anal Biochem. 1976;72:248-54. http://dx.doi.org/10.1016/0003-2697(76)90527-3

17. Singleton VL, Orthofer R. Analysis of total phenols and other oxidation substrates and antioxidants by means of Folin-Ciocalteu reagent. In: Abelson JN, Simon MI, Sies H, editors. Methods in enzimology, vol. 299. Burlington, MA, USA: Academic Press; 1999. pp. 152-78. http://dx.doi.org/10.1016/s0076-6879(99)99017-1
18. Uzunović A, Vranić E. Stability of anthocyanins from commercial black currant juice under simulated gastrointestinal digestion. Bosn J Basic Med Sci. 2008;8:254-8.

19. Piasecka-Kwiatkowska D, Warchalewski JR, Zielinska-Dawidziak M, Michalak M. Digestive enzyme inhibitors from grains as potential components of nutraceuticals. J Nutr Sci Vitaminol. 2012;58:217-20. http://dx.doi.org/10.3177/jnsv.58.217

20. Mandalari G, Bisignano C, Filocamo A, Chessa S, Sarò M, Torre G, et al. Bioaccessibility of pistachio polyphenols, xanthophylls, and tocopherols during simulated human digestion. Nutrition. 2013;29:338-44. http://dx.doi.org/10.1016/j.nut.2012.08.004

21. Manach C, Williamson G, Morand C, Scalbert A, Rémésy C. Bioavailability and bioefficacy of polyphenols in humans. I. Review of 97 bioavailability studies. Am J Clin Nutr. 2005; 81:230S-42S.

22. Stahl W, van den Berg H, Arthur J, Bast A, Dainty J, Faulks RM, et al. Bioavailability and metabolism. Mol Aspects Med. 2002;23:39-100. http://dx.doi.org/10.1016/S0098-2997(02)00016-X

23. Gawlik-Dziki U. Changes in the antioxidant activities of vegetables as a consequence of interactions between active compounds. J Funct Foods. 2012;4:872-82. http://dx.doi.org/10.1016/j.jff.2012.06.004

24. Martínez-Flóres S, González-Gallego J, Culebras JM. Tuñón MJ. Flavonoids: properties and antioxidant activity. Nutr Hosp. 2002;6:271-8 (in Spanish). http://dx.doi.org/10.3305\%2Fnutr+hosp.v17in06.3338

25. Eberhardt MV, Lee CY, Liu RH. Nutrition: antioxidant activity of fresh apples. Nature. 2000;405:903-4. http://dx.doi.org/10.1038/35016151

26. Thaipong K, Boonprakob U, Crosby K, Cisneros-Zevallos L, Hawkins Byrne D. Comparison of ABTS, DPPH, FRAP, and ORAC assays for estimating antioxidant activity from guava fruit extracts. J Food Comp Anal. 2006;19:669-75. http://dx.doi.org/10.1016/j.jfca.2006.01.003 